\title{
Geomorphological regionalization theory system and division methodology of China
}

\author{
WANG Nan ${ }^{1,2}$, CHENG Weiming ${ }^{1,2,3,4}$, WANG Baixue ${ }^{1,2}$, LIU Qiangyi ${ }^{1,2}$, \\ ZHOU Chenghu ${ }^{1,2}$
}

1. State Key Laboratory of Resources and Environmental Information System, Institute of Geographic Sciences and Natural Resources Research, CAS, Beijing 100101, China;

2. University of Chinese Academy of Sciences, Beijing 100049, China;

3. Jiangsu Center for Collaborative Innovation in Geographical Information Resource Development and Application, Nanjing 210023, China;

4. Collaborative Innovation Center of South China Sea Studies, Nanjing 210093, China

\begin{abstract}
Geomorphological regionalization (geomor-region) and geomorphological type (geomor-type) classification are two core components in the geomorphologic research. Although remarkable achievements have been made in the study of geomor-region, many deficiencies still exist, such as the inconsistency of landform indicators, the small quantity of division orders, disparities of geomorphological characteristics, differences of mapping results, and the small scale of zoning maps. Requirements for improved national geomor-regions are therefore needed for the purpose of an enhanced national geo-information system. Based on theories of geomor-region in China including plate tectonics, crustal features, endogenic and exogenic forced geomorphological features, and regional differentiations of geomor-type, a three-order (major-region, sub-region, and small-region) research program on China's geomor-regions is proposed on the basis of previous 2013 geomor-region system. The major contents of the new geomor-region scheme are: (1) principles of the national multi-order geomor-regions; (2) hierarchical indicator systems of geomor-regions including characteristics of the terrain ladder under the control of tectonic setting, combinations of regional macro-form types, combinations of endogenic and exogenic forces and basic types of morphology, combinations of regional morphological types, and combinations of regional micro-morphological types; (3) naming rules and coding methods of geomor-regions; and (4) precise positioning techniques and methods of multi-order geomor-region divisions based on multi-source data. Using the new geomor-region theory and division methodology, the partition of national three-order geomor-regions of China was successfully constructed. The geomor-region system divided China into six first-order major-regions, 36 second-order sub-regions, and 136 third-order small-regions. In addition, a database and management information system of the national geomor-regions were estab-
\end{abstract}

Received: 2019-06-26 Accepted: 2019-08-07

Foundation: National Natural Science Foundation of China, No.41590845, No.41421001, No.41571388

Author: Wang Nan (1990-), PhD, specialized in disaster GIS. E-mail: wangn.14s@igsnrr.ac.cn

*Corresponding author: Cheng Weiming (1973-), PhD and Professor, specialized in digital geomorphology and GIS.

E-mail: chengwm@1reis.ac.cn 
lished. This research has an important guiding significance for promoting the development of China's regional geomorphology and for practical applications based on geomor-regions.

Keywords: geomorphological regionalization; geomorphological types; hierarchical system; China

\section{Introduction}

Geomorphology is a basic component of natural environment studying surface morphology of the Earth, which is the carrier of human productivity and life (Zhou, 2006; You and Yang, 2013). The complex and changeable geomorphology of the Earth not only restricts the variation of climate, vegetation, soil, hydrology, and other physical factors at different scales, but also controls the differentiation of natural environment. Therefore, the science of geomorphology is of vital importance and powerful assistance for environmental studies. Geomorphologic studies can be divided into two categories, geomorphological type (geomor-type) classification and geomorphological regionalization (geomor-region), which are two most basic geomorphic units (Zhou, 2006; You and Yang, 2013). Geomor-type refers to the entity within which the geomorphic form and origin are identical. It can be repeated in space, such as an alluvial plain. A geomor-region is a region divided based on similarities and differences of morphology, origin, and development. Different from geomor-type, geomor-region is non-repeatable in space, such as the North China Alluvial Plain (Shen, 1961). For purposes of different geomorphological studies, geomor-regions can be divided into comprehensive geomor-regions, departmental geomor-regions, and special geomor-regions (Shen, 1961).

Studies on geomor-regions gradually emerged with the development of regional research. Since the 1930s, a large number of studies have been documented that put forward geomor-region schemes of China through compiling various atlases and monographs of geomor-regions (Li and Zhang, 1953; Zhou and Shi, 1956; RZCCAS, 1959; Chen, 1991; Guo and Cui, 2013, Li et al., 2013). To satisfy different application demands, a variety of local geomor-region schemes have been proposed by provinces, autonomous regions, and municipalities. In some regions, such as Northeast China and the Tibetan Plateau, distinct geomor-region programs were also proposed accordingly (GLNIGR, 1964; Gong, 1985; IGCAS, 1990).

Based on analysis of similarities and differences in the past and existing research, it was concluded that the geomor-region schemes proposed by predecessors are quite different in various aspects. Firstly, the indicator systems proposed at different times were distinct. Before the 1960s, geomor-regions were divided mainly based on structural landforms. In contrast, after the 1980s, morphological landforms played a dominant role in the geomor-region division. Secondly, the purposes of application were varied in different periods. In the early stage, depiction of the geomorphological characteristics was the priority. However, in recent years, the utilization of resources has become the main trend. Thirdly, the details of regional research were varied spatially. Studies in eastern China have been more comprehensive and verified compared with studies in the western part of China where historical data and materials were limited. In addition to the spatio-temporal discrepancies in the study of geomor-regions, two main deficiencies can be identified from the existing research: (1) the small-scale geomor-region maps do not match with other geographical factors, which 
weakens the controlling role of the geomorphological boundaries; and (2) the incomplete classification systems, most of which consist of only two or three orders, are not detailed enough to meet the needs of modern environmental and resource planning and decision making. Consequently, the establishment of a complete multi-order geomor-region scheme of China is an extremely necessary and pressing research subject.

In this study, we summed up the existing geomor-region schemes at multiple levels (i.e. national, regional, and provincial), and proposed a new three-order geomor-region scheme on a national scale for the first time. The scheme is composed of three main sections. Firstly, a model for the calculation of division indicators at each order is selected. Secondly, the naming rules and coding methods of geomor-regions at all orders are defined. Finally, a systematic database of the geomor-regions is established. Based on multi-source data, this study presents a precise division scheme of geomor-regions at three orders and provides a more accurate basis and controllable data background for China's resource utilization, ecology, and environmental management.

\section{Theory of geomor-region in China}

\subsection{Plate tectonics and geomorphological characteristics}

At the end of the 20th century, the presentation of the crust plate theory represented a landmark revolution in the history of geomorphological research. The theory analyzed the endogenic forces associated with the differentiation of geomorphic features, and thus explained the linkage mechanism between the characteristics of surface morphology and the tectonic activities of deep crustal plates (Pamsay and Huber, 1987; Ren et al., 1999; Summerfield, 2000; ESDSRG, 2002). The results showed that the formation dynamics of intercontinental landforms are mainly controlled by tectonic movements and are affected at the same time by exogenic forces, such as climate. Therefore, the movement of continental and oceanic plates is the basic driving force for the formation of modern geomorphological patterns. The global crust was divided into several schemes by combining modern plate location with geomorphological cycles, thus forming a relatively complete global tectonic system (Pamsay and Huber, 1987; Ren et al., 1999; Summerfield, 2000; ESDSRG, 2002).

Under the background of global plate tectonic movement, the first- and second-order geomorphic units in China are mostly determined based on geomorphic tectonics. They have undergone many tectonic changes. Some large mountain ranges went through multi-cyclic orogenies. Especially for the Mesozoic, constrained by the Indosinian movement and the Yanshan movement, a tectonic framework corresponding to the modern macro-geomorphological outline of China was established (Ren et al., 1999; You and Yang, 2013). Accordingly, the geomorphic unit formed by plate tectonics is the controlling basis of the geomor-region system.

The geomorphic layer is distributed on the Earth's surface, similar as the lithosphere, hydrosphere, and atmosphere, which was proposed in the Encyclopedia of Geomorphology in 1968. The internal structure of the Earth's crust is mainly determined by endogenic forces, whereas the external morphology is formed by exogenic forces (Chen, 2012). 


\subsection{Geomorphological features and forces}

\subsubsection{Endogenic forces of geomorphology}

China is located in the southeast of the Eurasian continental plate, with the western Pacific and Philippine plates to the east and the Indian plate to the southwest (Ren et al., 1999; You and Yang, 2013). Influenced by the interactions of these plates, three distinct geotectonic units are formed in China, the geosynclinal fold area, platform area, and continental margin active zone, resulting in the overall three-level terrain ladder characteristics of China's geomorphology (RZCCAS, 1959). At the same time, the arrangement and combination of some basic geomor-types, such as mountain ranges, plateaus, plains, and basins, are also controlled by geological structures. In particular, the extension of mountain ranges and the strike of tectonic lines are almost the same. Because of the considerable divergence of geological development history and tectonic stress in different parts of China, obvious spatial differences exist in the distribution of tectonic landforms (Chen, 2012; You and Yang, 2013).

\subsubsection{Exogenic forces of geomorphology}

Under the framework control of tectonic landforms formed by endogenic forces, the external morphology of a landform is changed constantly and continuously by exogenic forces. Because of various natural geographical conditions, climate factors play a dominant role in the transformation of landforms, and affect weathering, transport, and accumulation through regional differences in precipitation and temperature (Chen, 2012; You and Yang, 2013). Influenced by continentality and the terrain ladder, there are several obvious precipitation isolines from west to east. The $250 \mathrm{~mm}$ annual precipitation isoline is roughly coincident with the boundary between semi-desert and grassland, the $400 \mathrm{~mm}$ annual precipitation isoline is approximately the same as the boundary of forests and grassland, and the $800 \mathrm{~mm}$ annual precipitation isoline is along the southern foot of the Qinling Mountains and Huaihe River (RZCCAS, 1959). Hydrological condition is another key factor. The rate of channel flow and the level of surface erosion to a great extent affect the speed of geomorphological development, the extent of the segmentation of highlands, and the filling of lowlands, especially at the boundary between inland and outflow areas along the western foot of the Da (Greater) Hinggan Mountains to the Tibetan Plateau. The nature and integrity of natural vegetation on the ground and the utilization of land by human beings also greatly affect the development of landforms (Chen, 2012; You and Yang, 2013).

The classification of geomor-types in China is mostly based on a combination of morphology and genesis (IGCAS, 1987). In the study of Chinese geomor-types classification, geomorphologists have divided endogenic and exogenic forces of landform formation into six categories and 15 types. These are (1) water-related types including marine, lacustrine, and fluvial landforms, (2) ice-related types including glacial and periglacial landforms, (3) hot and arid climate-related types including aeolian and desiccation landforms, (4) special material-related types including loess and karst landforms, (5) tectonic-related types including volcanic lava, gravity, and tectonic landforms, and (6) other related types including anthropogenic, biological, and other active landforms (Chai et al., 2009; ECGAPRC, 2009; Zhou et al., 2009a; 2009b; Cheng et al., 2011; Cheng and Zhou, 2011; Cheng and Zhou, 2014; Cheng et al., 2017a; Cheng et al., 2017b; Cheng et al., 2017c; Cheng et al., 2018a). 


\subsection{Type and regional differentiation of geomorphological morphology}

\subsubsection{Type differentiation and type structure of geomorphological morphology}

In terms of basic morphology, China can be divided into mountain, plateau, hill, basin and plain areas. The areas of mountains and plateaus account for majority of China, followed by basins, while smaller proportions are for hills and plains (You and Yang, 2013). Mountains and plateaus are the main components of the basic outline of China's geomorphology. In particular, the crisscrossing mountain systems constitute the basic framework of the large-scale geomorphological outline, which controls the spatial distribution of basins, plains, and hills. In the classification study of multi-scale landform types in China, geomorphologists proposed that the basic geomor-types in China consist of four elevation grades and seven relief features resulting in a total of 25 geomor-types. Similarity analysis of these combined 25 basic geomor-types showed that plains and hills are dominant in the east and mountains are dominant in the west. A good coupling relationship was found between the characteristics of these combinations and China's three-level terrain ladder (Chai et al., 2009; ECGAPRC, 2009; Zhou et al., 2009a; 2009b; Cheng et al., 2011; Cheng and Zhou, 2011; Cheng and Zhou, 2014; Cheng et al., 2017a; 2017b; 2017c; 2018a).

2.3.2 Regional differentiation and regional structure of geomorphological morphology

China's topography is dominated by mountains and plateaus, and gradually declines from west to east (RZCCAS, 1959; You and Yang, 2013). The Tibetan Plateau, known as the "Roof of the World", is situated in the west of China, and hosts many famous high-elevation mountain systems. The Himalayas, located along the southwest border, are one of the youngest uplifted high-terrain mountain systems on the Earth, while the main peak, Mount Qomolangma (also called Mount Everest), is known as the "Peak of the Earth". There are many mountains and huge basins distributed in the northwest of China, with modern glaciers at the tops of mountains. In eastern China, the mountains have a crisscrossing pattern, with plateaus, basins, and plains intersected among them (RZCCAS, 1959; You and Yang, 2013). In China, there are many tall mountains and large geomorphic units surrounded or separated by these mountains with certain regularity, showing the cross-distribution characteristics of two major morphologic strikes of near E-W trending and N-E or N-N-E trending. Geological structure is the prime cause for the formation of the crossed intersecting features of near E-W trending and N-E or N-N-E trending geomorphology, which is a structural form that emerged through structural changes and is the result conforming to the geological structure (RZCCAS, 1959; You and Yang, 2013).

\section{Research on geomor-regions in China}

\subsection{Research progress of geomor-regions in China}

The study of geomor-regions in China has a history of more than 70 years (Li, 1953; Zhou et al., 1956; RZCCAS, 1959; Shen, 1961; Gong, 1985; Chen, 1991; Guo and Cui, 2013; Li et al., 2013; You and Yang, 2013). Various geomor-region schemes have emerged due to the diversity of research levels and application purposes.

In 1953, Li and Zhang (1953) proposed the first geomor-region scheme in a book on 
China's geographic division in modern Chinese history, which divided geomor-regions in accordance with geological structure. In 1956, Zhou et al. put forward another draft of China's geomor-region scheme based on a summary of previous research. They summarized several existing schemes proposed by Ren (21 geomor-regions), Xu (19 geomor-regions), Yaguang Press (19 geomor-regions), and Chen et al. (22 geomor-regions). The new version adopted the plan of dividing China into three first-order major-regions, namely, Tibetan Region, Meng-Xin (Inner Mongolia-Xinjiang) Region, and Eastern Region and 29 second-order sub-regions. Since then, more detailed work has been done to formulate the geomor-region scheme. In 1959, Shen et al. suggested to divide China into 18 first-order major-regions, 55 second-order sub-regions, and 114 third-order small-regions in the book Preliminary Draft of China's Geomorphological Regionalization. This is the first systematic geomor-region system in China, in which the principles and basis for the division of geomor-region were put forward (RZCCAS, 1959). Chen (1991) advanced the proposal of dividing China into four first-order major-regions, eight sub-regions, and 36 small-regions when compiling Chinese agricultural regionalization. Li et al. (2013) analyzed and summarized the relevant research on geomor-region at home and abroad, and divided China into six first-order major-regions and 37 second-order sub-regions.

\subsection{Main problems for geomor-region study in China}

A great deal of work has been carried out on the depiction of geomor-region boundaries in China. However, previous studies were unsatisfactory because of shortcomings in the disunity and inconsistency of the division system, as well as limitations of the cartographic scale and incompleteness of the application function.

\subsubsection{Disunity of the division system}

The division system refers to the skeleton and the orders of the geomor-region scheme. On one hand, the documented schemes showed divergence in the number of orders. Before 1959, most researchers adopted a two-order scheme. However, after 1959, three-order schemes became predominant (except one released in 2013). On the other hand, the numbers of regions at each order were quite distinct. Before 1959, most studies divided China into three first-order major-regions and approximately 20 second-order sub-regions. However, the Preliminary Draft of China's Geomorphological Regionalization published in 1959 proposed to divide China into 18 first-order major-regions. In addition, schemes published in 1991 and 2013 divided China into three and six first-order major-regions, respectively. The disunity of the division system indicates that the study of geomor-region in China has failed to organically combine the geological structure system with the geomor-type, resulting in a disunified hierarchical system of geomor-regions.

\subsubsection{Inconsistency of the division indicators}

Division indicators refer to the influencing factors considered in the process of programming. Through analysis and comparison, it was found that the existing indicator systems of geomor-regions differ considerably. Before the 1960s, tectonic landforms were given the first priority, whereas after the 1980s, morphological landforms were given the first in the 
scheme. In 1956, Zhou et al. divided Chinese geomorphology according to the geological structure (Zhou et al., 1965). In 1959, the indicators proposed in the Preliminary Draft of China's Geomorphological Regionalization not only considered geological structural characteristics, but also referred to external morphological differences (RZCCAS, 1959). In 1991, the first-order major-regions were divided mainly based on regional coordination and unity of the interactions between endogenic and exogenic forces, whereas the second-order sub-regions and third-order small-regions mostly took the similarity and combination characteristics of external morphology into account (Chen, 1991). The new geomor-region scheme proposed in 2013 put forward that the basic similarities and differences of geomorphic type combination and geomorphic genetic type were the basis of geomor-regions at each order.

\subsubsection{Limitation of the cartographic scale}

The cartographic scale reflects the details that depicted in geomor-region maps. Historical researches showed great spatial differences in the amount of information and details of the boundaries reflected in geomor-region maps because of the divergence of available data. The vast amount of accessible materials in eastern China, which has detailed division, is in deep contrast with the western part, where available data is sparse, and the division was done more roughly (RZCCAS, 1959; Zhou et al., 1965). In addition, the cartographic scale of published geomor-region maps was small, which did not match with other geographic factors. The scale of the geomor-region map published in 1959 was 1:15,000,000, which is the largest scale of a geomor-region map (RZCCAS, 1959). In addition, because of the limitations of data sources, most published geomor-regions were derived from the available smalland medium-scale topographic maps, seldom taking the comprehensive utilization of multi-source data into consideration. Single data sources resulted in low accuracy of division and the singleness of macroscopic law. Accordingly, geomor-regions with low resolution can hardly be used as the controlling boundaries for precious quantitative analysis.

\subsubsection{Incompleteness of the application function}

The application function of geomor-regions has been changing over time. In the early stage, the main application function for geomor-regions was the reflection of geomorphological characteristics (Zhou et al., 1956), and researchers then put more emphasis on the utilization of resources when making a geomor-region scheme (Chen, 1991; Guo and Cui, 2013). In the 1960s, as agricultural resources played a crucial role in China, the primary task for agricultural geomor-regions was to demonstrate the potential of agricultural resources and the spatial differences of national agricultural patterns (Chen, 1991; Guo and Cui, 2013). In recent years, ecological and environmental issues have become a national end-point concern, and there is an urgent need for a complete, fine-scale geomor-region system that meets the demands of current ecological and environmental conditions in China.

\section{New schemes of geomor-regions in China}

\subsection{Principles of geomor-regions in China}

The principles of geomor-regions are the criteria for studying and dividing geomor-regions, 
which have been addressed by many predecessors (Shen, 1961; Li et al., 2013; Cheng et al., 2019). Among these principles, most of them focus on the characteristics of regional differentiation, the consistency of morphology and cause of formation, and the dominant factors, etc. This study put more emphasis on the principles of regional differentiation, consistency of regional morphology, and cause of formation, especially the principle of multi-order series regionalization.

\subsubsection{Principle of regional differentiation}

Geomor-region should objectively reflect the similarities and differences of regional geomorphology. It not only reveals the law of regional spatial differentiation of geomorphology, but also clearly delineates the differences of geomorphological structure from a regional perspective. Therefore, the geomor-region must be continuous, and the same geomor-region can only exist once in space (Shen, 1961; Chen, 1991; Li et al., 2013; You and Yang, 2013).

\subsubsection{Principle of geomorphological genesis}

Geomor-region is a kind of geographical zoning with special regional morphology, and should be based on the characteristics of the geomorphology itself. The main object of geomorphological research is the surface morphology and force conditions, and the geomor-region should be based on the similarity between the surface morphology and geomorphological genesis (Shen, 1961; Chen, 1991; Li et al., 2013; You and Yang, 2013). Endogenic and exogenic forces are the causes and conditions for the formation of landforms, which can be expressed through landforms. Higher-order geomor-regions should follow the control of endogenic forces, whereas lower-order ones should depend more on the similarities and differences of landforms caused by exogenic forces. Therefore, the principle of combining morphology with genesis should be adopted to construct and classify the order indicator of geomor-regions (Zhou et al., 2009a; 2009b).

\subsubsection{Principle of multi-order scheme}

Usually, geomor-regions can be divided into two or three orders (Chen, 1991; Li et al., 2013), and some even into four or five orders. The geomor-region system should embody a hierarchy, and there should be an inclusion relationship between higher and lower orders. At the same time, there should be a corresponding relationship between the division indicators and orders in higher and lower orders.

\subsection{Methods of naming and coding}

The published Chinese geomor-region schemes and achievements of Chinese geomorphic research have laid a solid foundation for drawing up a completed new scheme of Chinese geomor-region on a national scale (Li, 1953; Zhou et al., 1956; Shen, 1961; Chen, 1991; Guo and Cui, 2013; Li et al., 2013). In this paper, a new scheme of three-order geomor-region and a precise method of multi-order geomor-regions are proposed including calculation of the indicator system, identification of multi-order geomor-regions, and the definition of naming rules and coding methods.

\subsubsection{Hierarchical system}

China covers a vast territory, with various types of landforms and complex combinations. 
Restricted by the scale and accuracy, geomor-types and their combinations vary greatly in different regions. Therefore, a hierarchical system is usually adopted in research on national geomorphological regionalization, which means dividing the whole country into several major-regions, and then into several sub-regions and small-regions in turn downwards. From higher to lower orders, the combination of geomor-types is usually from complex to simple, the number of geomor-types in each geomor-region gradually decreases, and the scale of the combination of geomor-types becomes small. Names adopted in previous schemes were not consistent, and need to be standardized for popularization and application (Li, 1953; Zhou et al., 1956; RZCCAS, 1959; Shen, 1961; Gong, 1985; Chen, 1991; Guo and Cui, 2013; Li et al., 2013). Based on analysis and comparison for all the names published previously, this study presents the first time that the naming of geomor-region has been refined to three orders at the national scale. The first-order, second-order, and third-order regions were defined as major-regions, sub-regions, and small-regions, with detailed naming methods provided in section 4.2.2.

\subsubsection{Naming principles}

Considering the uniqueness and non-repeatability of geomor-regions in space, the naming method should follow the following principles. These are: (1) to inherit and retain traditional, reasonable, and recognized names, and to avoid or minimize the use of disputed names as much as possible; (2) naming in sequence according to the order of the first-order major-region, second-order sub-region, and third-order small-region; (3) naming is carried out in the order of place names first, then major geomor-types and their combinations, and then geomor-region orders; (4) place names are divided into administrative regions, macro topographic units, such as mountains, basins, and plateaus, in due order; (5) geomor-types and their combinations are named according to the topmost morphological types in the area; and (6) geomor-regions with similar geomorphological characteristics can be further divided by regional and azimuth names and their combinations, such as the eastern section of Taihang Mountains and the northern foot of Changbai Mountains, which can reflect the location and direction information of the geomor-region.

\subsubsection{Coding methods}

Following the naming method defined in this paper, the three-order names of geomor-regions are generally too long and are not flexible enough to be used in practical applications. Hence, to facilitate the analysis and statistics of the geographic characteristics in multi-order geomor-regions, a coding method of combining numbers and letters is proposed. The general coding methods and codes of geomor-regions adopted in this paper are given in Table 1 (Chen, 1991; Li et al., 2013).

Table 1 Examples of coding and naming methods of three-order geomor-regions in China

\begin{tabular}{clll}
\hline \multicolumn{1}{c}{ Order } & \multicolumn{1}{c}{ First-order major-region } & Second-order sub-region & \multicolumn{1}{c}{ Third-order small-region } \\
\hline Coding methods & Roman numerals & $\begin{array}{l}\text { Capitalized letter in } \\
\text { alphabetic order }\end{array}$ & Arabic numerals \\
& I, II, III... & A, B, C... & $1,2,3 \ldots$ \\
Region example & Eastern China plains, low & Northern and Eastern & Huang-Huai-Hai alluvial plain \\
& mountains and hills region & China plains sub-region & small-region \\
Coding example & I & IG & IG4 \\
\hline
\end{tabular}




\subsection{Calculation of the division indicators}

\subsubsection{Division lines of geomor-regions}

Generally, the distribution characteristics of geomor-types are represented as horizontal and vertical band spectra spatially (You and Yang, 2013). For example, from a coastal area to a piedmont area, the basic geomor-types (in terms of morphological genesis types), marine plain, alluvial-marine plain, alluvial plain, and diluvial plain, appear in order. From the foot to the top of a mountain, there are usually hilly platform, low mountain, middle mountain, high mountain, and extremely high mountain regions appearing in turn (Zhou et al., 2009a; $2009 \mathrm{~b}$ ). In addition, corresponding to the obvious horizontal and vertical distribution of exogenic forces, the division of geomor-region should also be based on the turning points of geomorphological characteristics in turn. Therefore, the delimitation of the boundary should follow the rules of: (1) the boundary of the geomor-region must be divided according to the abrupt boundaries of topographic characteristics, namely, the boundary is determined according to the "three lines" - the piedmont line, valley line, and slope break line (Zhou et al., $2009 \mathrm{a} ; 2009 \mathrm{~b}$ ); and (2) the hue, texture, and structure difference lines derived from remote sensing images are used as a location reference. The division of geomor-regions should ensure the integrity of the entities, and the truncation of geomorphic entity units should be avoided (Zhou et al., 2009a; 2009b).

\subsubsection{Division indicators of geomor-types}

By summarizing the classification methods of various geomor-types at home and abroad, Cheng and Zhou (2014) proposed a hierarchical classification system of multi-scale geomor-types, dividing China into three grades and nine levels. The first grade is the geomorphic types, consisting of macro landform and relief characteristics (first level), and topographic distribution and elevation difference (second level). The second grade is the geomorphic categories, which include geomorphic genesis, material composition, and geomorphic age, which comprise of the main type of endogenic and exogenic forces (third level), the action mode of main forces (fourth level), material composition and lithologic differences (eighth level), and the age of landform formation (ninth level). The third grade is the geomorphic forms, including the characteristics and scale of morphological assemblages (fifth level), the characteristics and scale of micro-geomorphic units (sixth level), and the slope gradient (seventh level) (Cheng and Zhou, 2014). Based on the data of multi-scale digital landform types in China, this classification system provides the data basis for the establishment and division of the grading system of geomor-regions in China (Zhou et al., 2009a; 2009b). The main data sources for this scheme include published national-regional-provincial geomor-region data, national multi-scale digital geomorphic data, multi-scale Digital Elevation Model (DEM), remote sensing images, geological data, and basic geographical data, etc.

\subsubsection{Division indicators of geomor-regions}

Geomor-region represents the regional study of geomorphological characteristics at a regional scale, including endogenic processes dominated by regional geomorphological morphology, regional surface composition, neotectonic movement, exogenic processes reflected by denudation and accumulation, and the history of geomorphological formation and evolution. It is a basic component of geomor-region research, and the main reflection of regional 
geomorphological similarities and differences.

Based on the macro-geomorphic characteristics of China, three-order geomor-region indicators are proposed, which consist of the terrain ladder characteristics under the control of geo-tectonics by combining the regional macro-morphological types with endogenic and exogenic forces and the basic morphological types. The indicator systems consist of three orders of regions. The first-order major-regions are constrained by the mega-structural geomorphic units. They reflect the differences of mega-contours caused by endogenic forces, such as the macro-patterns of mountains, plateaus, hills, basins, and plains under the control of the three-level terrain ladder in China. The combination of geomor-types controls the differentiation of exogenic forces macroscopically (You and Yang, 2013).

The second-order sub-regions are macro-morphological structure characteristics mainly referring to geomorphic units such as mountains, plateaus, hills, basins, and plains formed by exogenic forces, and reflecting the differences of exogenic forces in the region (You and Yang, 2013).

The third-order small-regions are combinations of geomorphological characteristics referring to the basic geomorphological spatial combinations dominated by exogenic forces (Cheng and Zhou, 2014). For example, an extremely high mountain region is dominated by mountain glaciation of Mount Bogda, the high mountain region is dominated by mountain periglaciation of Mount Bogda, the middle mountain region is dominated by mountain fluviation of Mount Bogda, and the low mountain and hilly areas are dominated by desiccation at the northern foot of the Tianshan Mountains, etc.

\subsubsection{Division method of geomor-regions}

The first-order major-regions are influenced by global plate tectonics and regional geological structures. China's terrain has obvious characteristics of a three-level ladder. The first terrain ladder is centered on the Tibetan Plateau, with an average elevation of more than $4,000 \mathrm{~m}$. The second terrain ladder consists of areas from the outer edge of the Tibetan Plateau to the Da Hinggan Mountains, Taihang Mountains, Wushan Mountains, and Xuefeng Mountains, with an overall average elevation of more than $1,000 \mathrm{~m}$, which is mainly composed of vast plateaus, large basins, and many high mountains. The third terrain ladder is the lowest terrain ladder including the vast plains and hills in eastern China. This ladder covers the Northeast China Plain, the Huang-Huai-Hai Plain, the Middle and Lower Reaches of the Yangtze River Plain, and the hills south of the Yangtze River, for which the elevation is generally below $500 \mathrm{~m}$ (You and Yang, 2013). China's geomor-regions were initially determined based on the characteristics of these three distinct terrain ladders with two obvious marking lines. One feature marking line is the outline of the Tibetan Plateau, delineated by the altitude of $3500 \mathrm{~m}$, and the other is the boundary of the second and third ladders, separated by the altitude of $1000 \mathrm{~m}$. These marking lines are also the basis for the classification of geomor-types in terms of low, middle, and high altitudes.

According to the scheme of geotectonic division, China is divided into three tectonic units including the geosynclinal fold unit, the platform unit, and the active belt of the continental margin unit (Ren et al., 1999). Based on these geotectonic units, the boundaries of the first-order major-regions in China can be determined by combining the important landmarks of the third-level terrain ladder with the dividing lines of the three major types of geomor- 
phic units.

The second-order sub-regions are controlled by the geotectonic platform, geosyncline, and continental margin active zone resulting from distinct exogenic forces and morphology. China can be divided into two main geomorphic units: (1) denudation-dominated units (mountains, plateaus, and hills) and (2) accumulation-dominated units (plains and basins). Based on the first-order-level geotectonic division and referring to the second-order-level geotectonic division, the second-order geomor-regions were established under the framework of a mountain-plateau-hill assemblage and a plain-basin assemblage. The precise boundaries are depicted based on indicators derived from DEM images and the basic geomor-types.

The third-order small-regions are based on the two types of geomorphic zoning units (second-order sub-regions) of mountain-plateau-hill assemblages and plain-basin assemblages. These regions are refined with the aid of basic morphological types and geomorphic genesis types, and form a combination of denudation-dominated mountain-hill regions and a combination of accumulation-dominated plain regions. The boundaries of the third-order small-regions are a combination of basic geomor-types and basic genesis types based on the multi-scale geomor-type data.

\subsection{First-order, second-order, and third-order geomor-region scheme in China}

\subsubsection{First-order major-region}

In this paper, we proposed that China is divided into six first-order major-regions, including Eastern China Plains-Low Mountains-Hills Region I, Southeastern China Low Mountains-Hills-Plains Region II, Northern China-Eastern Inner Mongolia Middle Mountains-Plateaus Region III, Northwestern China High and Middle Mountains-Basins-Plateaus Region IV, Southwestern China Middle and Low Mountains-Plateaus-Basins Region V, and the Tibetan Plateau High and Extremely High Mountains-Basins-Valleys Region VI. Among them, Region VI is located on the first terrain ladder in China, Regions III, IV, and V constitute the second terrain ladder, whereas Regions I and II constitute the third terrain ladder.

The first-order division scheme is basically in accordance with Li's division method (Li et al., 2013; You and Yang, 2013) with minor differences of region names. In this study, we put more emphasis on the combination characteristics of the main landform types in each region when determining the region names. For purpose of more widely acceptance, the naming in this paper mainly follows the universality and tradition of Chinese conventions in naming major-regions.

\subsubsection{Second-order sub-region and third-order small-regions}

Within the framework of first-order major-regions, some detailed analyses have been performed to obtain 36 second-order sub-regions and third-order small-regions. As a result, the I to VI major-regions were divided into 8, 5, 5, 5, 5, and 8 sub-regions, and 28, 23, 19, 25, 20, and 21 small-regions, respectively (Figure 1 and Tables 2-7). Compared with the division scheme proposed by Li et al. (2013), we aggregated the 37 second-order sub-regions into 36 ones, and their names were adjusted correspondingly (Li et al., 2013; You and Yang, 2013). 


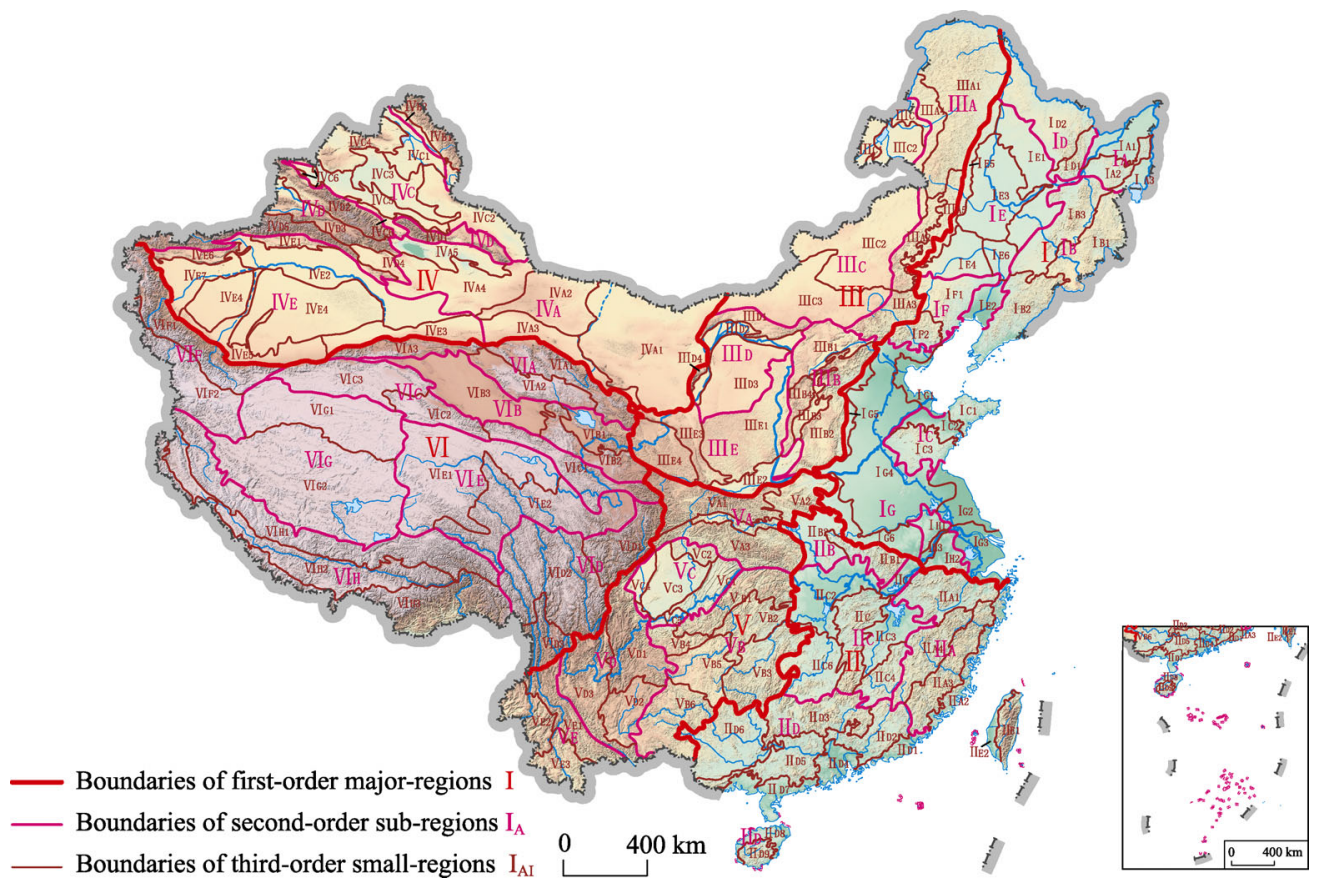

Figure 1 Three-order geomorphologic regionalization (geomor-regions) in China (The names and codes of geomor-regions are shown in Tables 2-7.)

Table 2 Names and codes of the second-order sub-regions and third-order small-regions of Eastern China Plains-Low Mountains-Hills Region I

\begin{tabular}{|c|c|c|c|}
\hline \multicolumn{2}{|r|}{ Second-order sub-regions } & \multicolumn{2}{|r|}{ Third-order small-regions } \\
\hline Codes & Names & Codes & Names \\
\hline \multirow[t]{3}{*}{ IA } & Wanda Mt and Sanjiang & IA1 & Sanjiang alluvial plains small-region \\
\hline & Plain low mountains and & IA 2 & Wanda Mt low mountains and hills small-region \\
\hline & & IA3 & Xingkai Lake alluvial-lacustrine plains small-region \\
\hline \multirow[t]{3}{*}{ IB } & Changbai Mt middle and & IB1 & Changbai Mt middle and low mountains, lava platforms small-region \\
\hline & low mountains, platforms & IB2 & Eastern Liaoning low mountains and hills small-region \\
\hline & & IB3 & Zhangguangcai Mt middle and low mountains and hills small-region \\
\hline \multirow[t]{3}{*}{ IC } & Eastern Shandong low & $\mathrm{IC} 1$ & Jiaodong low mountains and hills small-region \\
\hline & mountains, hills and plains & $\mathrm{IC} 2$ & Jiaolai alluvial plains small-region \\
\hline & & IC3 & Central Shandong middle and low mountains and hills small-region \\
\hline \multirow[t]{2}{*}{ ID } & Xiao Hinggan Mt low & ID1 & Eastern Xiao Hinggan Mt low mountains and hills small-region \\
\hline & $\begin{array}{l}\text { mountains, hills and } \\
\text { platforms sub-region }\end{array}$ & ID2 & Western Xiao Hinggan Mt hills and lava platforms small-region \\
\hline \multirow[t]{6}{*}{ IE } & $\begin{array}{l}\text { Songhua River-Liaohe } \\
\text { River Plains sub-region }\end{array}$ & IE1 & $\begin{array}{l}\text { Xiao Hinggan and Dahei Mts piedmont alluvial-diluvial plains and } \\
\text { platforms small-region }\end{array}$ \\
\hline & & IE2 & Lower reaches of Liaohe River alluvial-marine plains small-region \\
\hline & & IE3 & Songhua River-Nenjiang River alluvial-lacustrine plains small-region \\
\hline & & IE4 & Upper reaches of Liaohe River diluvial-alluvial plains small-region \\
\hline & & IE5 & Eastern foot of Da Hinggan Mts hills small-region \\
\hline & & IE6 & Middle reaches of Liaohe River alluvial plains small-region \\
\hline
\end{tabular}


(Continued)

\begin{tabular}{|c|c|c|c|}
\hline \multicolumn{2}{|r|}{ Second-order sub-regions } & \multicolumn{2}{|r|}{ Third-order small-regions } \\
\hline Codes & Names & Codes & Names \\
\hline \multirow[t]{2}{*}{ IF } & Yanshan Mts \& western & IF1 & Western Liaoning hills and platforms small-region \\
\hline & $\begin{array}{l}\text { Liaoning low mountains, } \\
\text { hills and platforms sub-region }\end{array}$ & IF2 & Yanshan Mt low mountains and hills small-region \\
\hline \multirow[t]{6}{*}{ IG } & Northern and Eastern China & IG1 & Bohai Sea marine plains small-region \\
\hline & plains sub-region & IG2 & Northern Jiangsu lacustrine-marine plains small-region \\
\hline & & IG3 & Jiangsu and Zhejiang alluvial delta plains small-region \\
\hline & & IG4 & Huang-Huai-Hai alluvial plain small-region \\
\hline & & IG5 & Piedmont of Taihang Mts diluvial-alluvial plains small-region \\
\hline & & IG6 & Piedmont of Funiu and Dabie Mts alluvial-diluvial plains small- region \\
\hline \multirow[t]{3}{*}{$\mathrm{IH}$} & Ningzhen plains, hills and & IH1 & Chuzhou low mountains, hills, mounds and plains small-region \\
\hline & mounds sub-region & IH 2 & Southern Yangtze River hills and plains small-region \\
\hline & & IH3 & Nanjing lower reaches of Yangtze River Plains small-region \\
\hline
\end{tabular}

Table 3 Names and codes of the second-order sub-regions and third-order small-regions of Southeastern China Low Mountains-Hills-Plains Region II

\begin{tabular}{|c|c|c|c|}
\hline \multicolumn{2}{|r|}{ Second-order sub-regions } & \multicolumn{2}{|r|}{ Third-order small-regions } \\
\hline Codes & Names & Codes & Names \\
\hline \multirow[t]{4}{*}{ IIA } & \multirow{4}{*}{$\begin{array}{l}\text { Zhejiang and Fujian middle } \\
\text { and low mountains, hills and } \\
\text { valleys sub-region }\end{array}$} & IIA1 & $\begin{array}{l}\text { Zhejiang and Anhui middle and low mountains, hills and valleys } \\
\text { small-region }\end{array}$ \\
\hline & & IIA2 & Zhejiang and Fujian costal low mountains, hills and plains small-region \\
\hline & & IIA3 & $\begin{array}{l}\text { Central Zhejiang and Fujian middle and low mountains, hills and valleys } \\
\text { small-region }\end{array}$ \\
\hline & & IIA4 & Wuyi Mt middle and low mountains, hills and valleys small-region \\
\hline \multirow[t]{2}{*}{ IIB } & \multirow[t]{2}{*}{$\begin{array}{l}\text { Huaiyang low mountains, } \\
\text { hills and mounds sub-region }\end{array}$} & IIB1 & $\begin{array}{l}\text { Tongbai and Dabie Mts middle and low mountains and hills small- } \\
\text { region }\end{array}$ \\
\hline & & IIB2 & Nanyang Basin low mountains, hills, platforms and plains small-region \\
\hline \multirow[t]{6}{*}{ IIC } & \multirow{6}{*}{$\begin{array}{l}\text { Middle reaches of Yangtze } \\
\text { River low mountains, hills, } \\
\text { plains and basins sub-region }\end{array}$} & IIC1 & Middle reaches of Yangtze River alluvial plains small-region \\
\hline & & IIC2 & Jianghan lacustrine-alluvial plains small-region \\
\hline & & IIC3 & Poyang Lake hills, mounds, alluvial-lacustrine plains small-region \\
\hline & & IIC4 & Southern Jiangxi low mountains, hills and basins small-region \\
\hline & & IIC5 & $\begin{array}{l}\text { Mufu and Luoxiao Mts middle and low mountains, hills and basins } \\
\text { small-region }\end{array}$ \\
\hline & & IIC6 & $\begin{array}{l}\text { Central-southern Hunan middle and low mountains, hills and basins } \\
\text { small-region }\end{array}$ \\
\hline \multirow[t]{9}{*}{ IID } & \multirow{9}{*}{$\begin{array}{l}\text { Southern China low } \\
\text { mountains, hills and plains } \\
\text { sub-region }\end{array}$} & IID1 & $\begin{array}{l}\text { Eastern Guangdong coastal low mountains, hills, platforms and plains } \\
\text { small-region }\end{array}$ \\
\hline & & IID2 & $\begin{array}{l}\text { Eastern Guangdong low mountains, hills, parallel ridges and valleys } \\
\text { small-region }\end{array}$ \\
\hline & & IID3 & Nanling Mts middle and low mountains and basins small-region \\
\hline & & IID4 & Pearl River Delta plains small-region \\
\hline & & IID5 & Guangdong and Guangxi low mountains, hills and basins small-region \\
\hline & & IID6 & Western Guangxi karst low mountains, hills and basins small-region \\
\hline & & IID7 & Guangdong and Guangxi coastal hills, platforms and plains small-region \\
\hline & & IID8 & Northern Hainan platforms and plains small-region \\
\hline & & IID9 & Southern Hainan middle and low mountains and hills small-region \\
\hline \multirow[t]{2}{*}{ IIE } & \multirow{2}{*}{$\begin{array}{l}\text { Taiwan plains and } \\
\text { mountains of sub-region }\end{array}$} & IIE1 & Eastern Taiwan middle and low mountains and hills small-region \\
\hline & & IIE2 & Western Taiwan low mountains, hills and plains small-region \\
\hline
\end{tabular}


Table 4 Names and codes of the second-order sub-regions and third-order small-regions of Northern China-Eastern Inner Mongolia Middle Mountains-Plateaus Region III

\begin{tabular}{|c|c|c|c|}
\hline \multicolumn{2}{|r|}{ Second-order sub-regions } & \multicolumn{2}{|r|}{ Third-order small-regions } \\
\hline Codes & Names & Codes & Names \\
\hline \multirow[t]{4}{*}{ IIIA } & $\begin{array}{l}\text { Da Hinggan Mt middle and } \\
\text { low mountains sub-region }\end{array}$ & IIIA1 & $\begin{array}{l}\text { Northern Da Hinggan } \mathrm{Mt} \text { middle and low mountains and hills } \\
\text { small-region }\end{array}$ \\
\hline & & IIIA2 & $\begin{array}{l}\text { Southern Da Hinggan Mt middle and low mountains and hills } \\
\text { small-region }\end{array}$ \\
\hline & & IIIA3 & Northwestern Hebei middle and low mountains small-region \\
\hline & & IIIA4 & Da Hinggan Mt west slope low mountains and hills small-region \\
\hline \multirow[t]{4}{*}{ IIIB } & Shanxi middle and low & IIIB1 & Northern Shanxi middle and low mountains and basins small-region \\
\hline & mountains and basins & IIIB2 & Taihang Mt middle and low mountains and hills small-region \\
\hline & sub-region & IIIB3 & Central-southern Shanxi basins small-region \\
\hline & & IIIB4 & Lvliang Mt middle and low mountains and hills small-region \\
\hline \multirow[t]{3}{*}{ IIIC } & Northeastern Inner & IIIC1 & Hulun Buir plateau small-region \\
\hline & Mongolia high plains & IIIC2 & Xilin Gol plateau small-region \\
\hline & & IIIC3 & Ulanqab high plain small-region \\
\hline \multirow[t]{4}{*}{ IIID } & Ordos Plateau and Hetao & IIID1 & Yinshan Mt middle and low mountains small-region \\
\hline & Plains sub-region & IIID2 & Hetao alluvial plains small-region \\
\hline & & IIID3 & Ordos Plateau small-region \\
\hline & & IIID4 & Helan Mt subalpine mountains small-region \\
\hline \multirow[t]{4}{*}{ IIIE } & Loess Plateau sub-region & IIIE1 & Northern Shaanxi loessic ridges, tablelands and mounds small-region \\
\hline & & IIIE2 & Fenhe and Weihe diluvial-alluvial plains and platforms small-region \\
\hline & & IIIE3 & Liupan Mt middle and low mountains, hills and valleys small-region \\
\hline & & IIIE4 & Gansu middle mountains, loessic ridges and mounds small-region \\
\hline
\end{tabular}

Table 5 Names and codes of the second-order sub-regions and third-order small-regions of Northwestern China High and Middle Mountains-Basins-Plateaus Region IV

\begin{tabular}{|c|c|c|c|}
\hline \multicolumn{2}{|c|}{ Second-order sub-regions } & \multicolumn{2}{|r|}{ Third-order small-regions } \\
\hline Codes & Names & Codes & Names \\
\hline \multirow[t]{5}{*}{ IVA } & \multirow{5}{*}{$\begin{array}{l}\text { Inner Mongolia, Gansu } \\
\text { and Xinjiang plateaus, } \\
\text { hills and plains } \\
\text { sub-region }\end{array}$} & IVA1 & Alxa plateaus, hills, aeolian plains small-region \\
\hline & & IVA2 & Mazong Mt middle mountains and hills small-region \\
\hline & & IVA3 & Hexi Corridor alluvial-diluvial plains small-region \\
\hline & & IVA4 & Gaxun Gobi hills and basins small-region \\
\hline & & IVA5 & Turpan-Hami alluvial-diluvial plains small-region \\
\hline \multirow[t]{2}{*}{ IVB } & \multirow{2}{*}{$\begin{array}{l}\text { Altai Mt high and mid- } \\
\text { dle mountains sub-region }\end{array}$} & IVB1 & Altay Mt high and middle mountains small-region \\
\hline & & IVB2 & Altay Mt low mountains and hills small-region \\
\hline \multirow[t]{6}{*}{ IVC } & \multirow{6}{*}{$\begin{array}{l}\text { Junggar Basin } \\
\text { sub-region }\end{array}$} & IVC1 & Ulungur and Ertix rivers alluvial plains small-region \\
\hline & & IVC2 & Eastern Junggar Basin hills and plains small-region \\
\hline & & IVC3 & Gurbantunggut Desert small-region \\
\hline & & IVC4 & Western Junggar middle mountains and hills small-region \\
\hline & & IVC5 & Southern margin of Junggar Basin diluvial-alluvial plains small-region \\
\hline & & IVC6 & $\begin{array}{l}\text { Tianshan Mt north piedmont low mountains, hills and plains } \\
\text { small-region }\end{array}$ \\
\hline
\end{tabular}


(Continued)

\begin{tabular}{|c|c|c|c|}
\hline \multicolumn{2}{|c|}{ Second-order sub-regions } & \multicolumn{2}{|r|}{ Third-order small-regions } \\
\hline Codes & Names & Codes & Names \\
\hline \multirow[t]{5}{*}{ IVD } & \multirow{5}{*}{$\begin{array}{l}\text { Tianshan Mt high } \\
\text { mountains and basins } \\
\text { sub-region }\end{array}$} & IVD1 & Eastern Tianshan Mt high mountains small-region \\
\hline & & IVD2 & Northern Tianshan Mt high mountains small-region \\
\hline & & IVD3 & Central Tianshan Mt high mountains and basins small-region \\
\hline & & IVD4 & Yanqi Basin small-region \\
\hline & & IVD5 & Southern Tianshan Mt high mountains small-region \\
\hline \multirow[t]{7}{*}{ IVE } & Tarim Basin sub-region & IVE1 & Baicheng front range hills and basins small-region \\
\hline & & IVE2 & Northern Tarim River lacustrine-alluvial plains small-region \\
\hline & & IVE3 & $\begin{array}{l}\text { Southeastern margin of Tarim River alluvial-diluvial platforms and } \\
\text { plains small-region }\end{array}$ \\
\hline & & IVE4 & Taklimakan Desert aeolian dunes small-region \\
\hline & & IVE5 & Southern margin of Tarim River alluvial-diluvial plains small-region \\
\hline & & IVE6 & Keping front range hills and basins small-region \\
\hline & & IVE7 & Kashgar diluvial-alluvial plains small-region \\
\hline
\end{tabular}

Table 6 Names and codes of the second-order sub-regions and third-order small-regions of Southwestern China Middle and Low Mountains-Plateaus-Basins Region V

\begin{tabular}{|c|c|c|c|}
\hline \multicolumn{2}{|r|}{ Second-order sub-regions } & \multicolumn{2}{|r|}{ Third-order small-regions } \\
\hline Codes & Names & Codes & Names \\
\hline \multirow[t]{3}{*}{ VA } & \multirow{3}{*}{$\begin{array}{l}\text { Qinling-Daba Mts middle } \\
\text { and low mountains } \\
\text { sub-region }\end{array}$} & VA1 & Qinling Mts middle and high mountains small-region \\
\hline & & VA2 & $\begin{array}{l}\text { Southern Henan and Hanzhong middle and low mountains, hills and } \\
\text { valleys small-region }\end{array}$ \\
\hline & & VA3 & Daba Mt middle and low mountains and valleys small-region \\
\hline \multirow[t]{6}{*}{ VB } & \multirow{6}{*}{$\begin{array}{l}\text { Hubei-Guizhou-Yunnan } \\
\text { middle and low mountains } \\
\text { and valleys sub-region }\end{array}$} & VB1 & $\begin{array}{l}\text { Western Hubei plateau-Dalei Mt middle and low mountains, hilly pla- } \\
\text { teaus and valleys small-region }\end{array}$ \\
\hline & & VB2 & Wuling Mt middle and low mountains and valleys small-region \\
\hline & & VB3 & Xuefeng Mt middle and low mountains small-region \\
\hline & & VB4 & $\begin{array}{l}\text { Southern Sichuan-Northern Guizhou-Eastern Yunnan karst plateaus and } \\
\text { middle mountains small-region }\end{array}$ \\
\hline & & VB5 & $\begin{array}{l}\text { Central Guizhou karst middle mountains, hilly plateaus and basins } \\
\text { small-region }\end{array}$ \\
\hline & & VB6 & $\begin{array}{l}\text { Southern Guizhou-southeastern Yunnan karst plateaus and middle moun- } \\
\text { tains small-region }\end{array}$ \\
\hline \multirow[t]{5}{*}{$\mathrm{VC}$} & \multirow{5}{*}{$\begin{array}{l}\text { Sichuan Basin } \\
\text { sub-region }\end{array}$} & $\mathrm{VC} 1$ & Eastern Sichuan parallel low mountains, ridges and valleys small-region \\
\hline & & $\mathrm{VC} 2$ & Northern Sichuan Basin low mountains and hills small-region \\
\hline & & $\mathrm{VC} 3$ & Central Sichuan Basin hills and platforms small-region \\
\hline & & $\mathrm{VC} 4$ & Western Sichuan Basin alluvial plains small-region \\
\hline & & $\mathrm{VC} 5$ & Southern Sichuan Basin low mountains and hills small-region \\
\hline \multirow[t]{3}{*}{ VD } & \multirow{3}{*}{$\begin{array}{l}\text { Southwestern Sichuan } \\
\text { and Central Yunnan } \\
\text { Plateaus, middle and low } \\
\text { mountains and basins } \\
\text { sub-region }\end{array}$} & VD1 & Wumeng and Liangshan Mts middle and high mountains small-region \\
\hline & & VD2 & Central Yunnan karst plateaus middle mountains and valleys small-region \\
\hline & & VD3 & Yanyuan and Chuxiong plateaus middle mountains and basins small-region \\
\hline \multirow[t]{3}{*}{$\mathrm{VE}$} & \multirow{3}{*}{$\begin{array}{l}\text { Southwestern Yunnan } \\
\text { middle and high } \\
\text { mountains sub-region }\end{array}$} & VE1 & Southern Hengduan Mt middle and high mountains small-region \\
\hline & & VE2 & Western Yunnan middle mountains and basins small-region \\
\hline & & VE3 & Southwestern Yunnan middle mountains and valleys small-region \\
\hline
\end{tabular}


Table 7 Names and codes of the second-order sub-regions and third-order small-regions of the Tibetan Plateau High and Extremely High Mountains-Basins-Valleys Region VI

\begin{tabular}{|c|c|c|c|}
\hline \multicolumn{2}{|r|}{ Second-order sub-regions } & \multicolumn{2}{|r|}{ Third-order small-regions } \\
\hline Codes & Names & Codes & Names \\
\hline \multirow[t]{3}{*}{ VIA } & \multirow{3}{*}{$\begin{array}{l}\text { Altun \& Qilian Mts high } \\
\text { mountains and valleys } \\
\text { sub-region }\end{array}$} & VIA1 & Northern Qilian Mt high mountains and valleys small-region \\
\hline & & VIA2 & Southern Qilian Mt high mountains, valleys and basins small-region \\
\hline & & VIA3 & Altun Mt high and extremely high mountains small-region \\
\hline \multirow[t]{3}{*}{ VIB } & \multirow{3}{*}{$\begin{array}{l}\text { Qaidam Basin and Yellow } \\
\text { River-Huangshui River } \\
\text { high mountains and basins } \\
\text { sub-region }\end{array}$} & VIB1 & Yellow River and Huangshui River valleys and basins small-region \\
\hline & & VIB2 & South of Yellow River high mountains and basins small-region \\
\hline & & VIB3 & Qaidam Basin small-region \\
\hline \multirow[t]{3}{*}{ VIC } & \multirow{3}{*}{$\begin{array}{l}\text { Central and eastern Kunlun } \\
\text { Mt high mountains } \\
\text { sub-region }\end{array}$} & VIC1 & Eastern Kunlun Mt high mountains small-region \\
\hline & & VIC2 & $\begin{array}{l}\text { Eastern segment of central Kunlun Mt high mountains and plateaus } \\
\text { small-region }\end{array}$ \\
\hline & & VIC3 & $\begin{array}{l}\text { Western segment of central Kunlun Mt high mountains and lake } \\
\text { basins small-region }\end{array}$ \\
\hline \multirow[t]{3}{*}{ VID } & \multirow{3}{*}{$\begin{array}{l}\text { Hengduan Mt high } \\
\text { mountains and valleys } \\
\text { sub-region }\end{array}$} & VID1 & Daxue-Minshan Mt extremely high and high mountains small-region \\
\hline & & VID2 & $\begin{array}{l}\text { Northern section of Hengduan Mt high mountains and valleys } \\
\text { small-region }\end{array}$ \\
\hline & & VID3 & $\begin{array}{l}\text { Southern section of Hengduan Mt high mountains and valleys } \\
\text { small-region }\end{array}$ \\
\hline \multirow[t]{2}{*}{ VIE } & \multirow{2}{*}{$\begin{array}{l}\text { Sources of Three Rivers } \\
\text { high hilly mountains and } \\
\text { plateaus-upper reaches of } \\
\text { rivers mountains and } \\
\text { valleys sub-region }\end{array}$} & VIE1 & $\begin{array}{l}\text { Sources of Yangtze, Yellow and Lancang rivers hilly mountains and } \\
\text { plateaus small-region }\end{array}$ \\
\hline & & VIE2 & $\begin{array}{l}\text { Upper reaches of Three Rivers high mountains and valleys } \\
\text { small-region }\end{array}$ \\
\hline \multirow[t]{2}{*}{ VIF } & \multirow{2}{*}{$\begin{array}{l}\text { Karakorum \& western } \\
\text { Kunlun Mt high and } \\
\text { extremely high mountains } \\
\text { sub-region }\end{array}$} & VIF1 & Western Kunlun Mt high and extremely high mountains small-region \\
\hline & & VIF2 & $\begin{array}{l}\text { Karakorum Mt high and extremely high mountains, broad valleys and } \\
\text { basins small-region }\end{array}$ \\
\hline \multirow[t]{2}{*}{ VIG } & \multirow[t]{2}{*}{$\begin{array}{l}\text { Qiangtang Plateau lakes } \\
\text { and basins sub-region }\end{array}$} & VIG1 & $\begin{array}{l}\text { Hoh Xil plateau hilly mountains and plateaus and lake basins } \\
\text { small-region }\end{array}$ \\
\hline & & VIG2 & $\begin{array}{l}\text { Qiangtang Plateau high and extremely high mountains and lake ba- } \\
\text { sins small-region }\end{array}$ \\
\hline \multirow[t]{3}{*}{ VIH } & \multirow{3}{*}{$\begin{array}{l}\text { Himalayan high and } \\
\text { extremely high mountains } \\
\text { sub-region }\end{array}$} & VIH1 & $\begin{array}{l}\text { Nyainqentanglha and Gangdise Mts high and extremely high moun- } \\
\text { tains small-region }\end{array}$ \\
\hline & & VIH2 & $\begin{array}{l}\text { Northern Himalayas and Yarlung Zangbo River high mountains, } \\
\text { valleys and basins small-region }\end{array}$ \\
\hline & & VIH3 & Himalayan extremely high and high mountains small-region \\
\hline
\end{tabular}

\section{Application of geomor-regions in China}

\subsection{Farmland conversion}

Landforms affect the allocation of surface water, heat, soil, and organisms to a significant extent, and thus may have great influence on the type of land use and the structure of farmland. Cheng et al. (2018b) and Gao et al. (2019) analyzed farmland conversion during 1990-2015 in the first-order geomor-regions. Studies indicated that the loss of farmland occurred mostly in Regions II and V as a result of growing industrialization and urbanization, whereas the increase of farmland occurred mainly in Regions I and IV because of reclamation of grassland and wasteland. Some researchers have also discussed farmland changes on 
the regional scale, and distinctive spatial patterns can be detected in the regional geomor-regions with specific geomorphological characteristics and geotectonics. Li and Liu (1994) assessed agricultural lands in Gansu Province with seven diverse geomor-regions (including the Beishan Mountains Region, Alxa Plateaus Region, Gansu Corridor Region, Qilian Mountains Region, Gannan Plateau Region, and Longnan Mountains Region). Jin et al. (2017) focused on the conversion from wetland to farmland on the Sanjiang Plain, and determined the spatio-temporal dynamic change of land use within different geomor-types based on a long-term database.

\subsection{Natural hazards}

The topographic features of watersheds, including elevation, slope, aspect, etc., have a close relationship with natural hazards, such as flash flooding, debris flows, and landslides. Liu et al. (2017) analyzed the distribution characteristics of flash flooding in the six major-regions and revealed a relationship between disaster frequency and altitude. They found that regions with the highest disaster frequencies were Regions II and V, with flash flooding hazards clustering in the altitude ranges of 10-50 m and lower than $600 \mathrm{~m}$. In addition, the occurrence of specific natural hazards showed spatial differences due to various topographic and climatic conditions. Liu et al. (2009) proposed a geomorphological scheme that aimed to prevent and manage geologic hazards in Guangxi Province.

\subsection{Urban development}

The geomorphologic environment provides the underlying surface and foundation for urban development, and profoundly impacts urban regional structures, forms, landscapes, and functions (Diao et al., 1990). Zhao et al. (2016) studied the spatial differentiation and morphologic characteristics of urban core zones located in different geomor-regions in China using morphologic indices. The results showed that urban core zones were most widely distributed in the eastern region comprising hilly plains, with a decreasing distribution trend from northeast to southwest, and the least distribution on the Tibetan Plateau. Studies on regional urbanization levels over a long time series showed a close relationship with topographic features. The urbanization level was negatively correlated with relief amplitude and altitude. A high level of urbanization was found on low-altitude platforms and low-altitude plains, with gradual narrowing of gaps between these two geomor-types (Zhao et al., 2017). Li (1992) studied urban development characteristics of the Urumqi city, located in a gentle plain between two main geomor-regions with subsidence and a high-relief mountain with uplift, and analyzed disaster threats associated with geomorphic processes, such as earthquakes, flash flooding and landslides.

\section{Conclusion}

Geomorphological regionalization (geomor-region) and geomorphological type (geomor-type) classification are the two core components of geomorphological research. Many schemes have been proposed for the division of geomor-regions in China. However, there are still some shortcomings in the various documented schemes, such as disunity of the divi- 
sion scheme, inconsistency of division indicators, limitations of mapping scales, and incompleteness of application functions. Under the background of the Geographical and National Conditions Census in China, new requirements are put forward for a new geomor-region scheme with multiple orders on a national scale. In this paper, a complete three-order geomor-region division scheme and a systematic division method were established for the first time. The main progress and conclusions are as follows.

The complete three-order geomor-region division scheme of first-order major-regions, second-order sub-regions, and third-order small-regions in China on a national scale was proposed. In addition, a three-order division indicator system was established including the terrain ladder characteristics under the control of geo-tectonics, the combination of regional macro-scale geomor-types, and the combination of endogenic and exogenic forces and basic geomor-types.

Geotectonics was organically combined with geomor-types to complete the transformation from regional combination of geomor-types to geomor-regions. In addition, based on multiple sources of data, precise location technology, naming rules definition, and a coding method for the multi-order geomor-region scheme were discussed.

The division of the three-order geomor-regions in China has been completed including six first-order major-regions, 36 second-order sub-regions, and 136 third-order small-regions. A national database of geomor-regions has been established.

Research on geomor-region is a comprehensive and generalized complex work. Research findings in this study will promote the development of geomor-regions in China. However, some difficulties and challenges in several aspects still exist, such as the establishment of division scheme, the selection of division indicators, the demarcation of boundaries, and the application of results (Zhao et al., 2017; Cheng et al., 2018b). With continuous improvement of the theoretical system and technical methods, the study of geomor-regions will be more in-depth, and will better serve China's national economic construction and ecological environmental protection.

\section{Acknowledgments}

We thank Alex Boon, PhD, and Sara J. Mason, MSc, from Liwen Bianji, Edanz Editing China (www.liwenbianji.cn/ac), for editing the English text of a draft of this manuscript. We also thank Professor Liu Yongbo at the University of Guelph for checking and revising the language, and the editor and anonymous reviewers for their labor and precious time spent improving our manuscript.

\section{References}

Chai H X, Zhou C H, Chen X et al., 2009. Digital regionalization of geomorphology in Xinjiang. Journal of Geographical Sciences, 19(5): 600-614.

Chen Z M, 1991. The Chinese Geomorphological Regional Planning Maps. In: The Editorial Committee of Agricultural Resources and Regional Planning of China. Chinese Agricultural Resources and Regional Planning. Beijing: China Agricultural Press. (in Chinese)

Chen Z M, 2012. General Geomorphic Map of Land and Sea of Asia and Surrounding (1:8000000). Beijing: 
Surveying and Mapping Press. (in Chinese)

Cheng W M, Bao A M, Chai H X et al., 2018a. Geomorphological Patterns and Effects in Xinjiang. Beijing: Science Press. (in Chinese)

Cheng W M, Gao X Y, Ma T et al., 2018b. Spatial-temporal distribution of cropland in China based on geomorphologic regionalization during 1990-2015. Acta Geographica Sinica, 73(9): 1613-1629. (in Chinese)

Cheng W M, Liu Q Y, Zhao S M et al., 2017a. Research and perspectives on geomorphology in China: Four decades in retrospect. Journal of Geographical Sciences, 27(11): 1283-1310.

Cheng W M, Zhao S M, Ye Q H et al., 2017b. Patterns and Dynamics of Frigid Landforms in the Tibetan Plateau. Beijing: Science Press. (in Chinese)

Cheng W M, Zhou C H, 2011. Research and compilation of the Geomorphologic Atlas of the People's Republic of China (1:1000000). Journal of Geographical Sciences, 21(1): 89-100.

Cheng W M, Zhou C H, 2014. Methodology on hierarchical classification of multi-scale digital geomorphology. Progress in Geography, 33(1): 23-33. (in Chinese)

Cheng W M, Zhou C H, Li B Y et al., 2011. Structure and contents of layered classification system of digital geomorphology for China. Journal of Geographical Sciences, 21(5): 771-790.

Cheng W M, Zhou C H, Li B Y et al., 2019. Geomorphological regionalization theory system and division methodology of China. Acta Geographica Sinica, 74(5): 839-856. (in Chinese)

Cheng W M, Zhou C H, Shen Y C et al., 2017c. Retrospect and perspective of geomorphology researches in China over the past 40 years. Acta Geographica Sinica, 72(5): 755-775. (in Chinese)

Diao C T, 1990. The geomorphological environment and urban expanding in Chongqing. Journal of Southwest Teachers University, 15(4): 484-490. (in Chinese)

Earth Science Development Strategy Research Group (ESDSRG), Earth Science Division of Chinese Academy of Sciences, 2002. Earth Science: A Review and Prospect at the Turn of the Century. Jinan: Shandong Education Press. (in Chinese)

Editorial Committee of Geomorphologic Atlas of People's Republic of China (ECGAPRC), 2009. The Geomorphologic Atlas of People's Republic of China $(1: 1000000)$. Beijing: Science Press. (in Chinese)

Gao X Y, Cheng W M, Wang N et al., 2019. Spatio-temporal distribution and transformation of cropland in geomorphologic regions of China during 1990-2015. Journal of Geographical Sciences, 29(2): 180-196.

Geomorphology Laboratory, Northeast Institute of Geography Research (GLNIGR), Chinese Academy of Sciences, 1964. General Part of Northeast Geomorphological Regionalization (Draft): Changchun. (in Chinese)

Gong G Y, 1985. Geomorphological Regionalization of Huang-Huai-Hai Plain. Beijing: Institute of Geography, Chinese Academy of Sciences. (in Chinese)

Guo Z L, Cui G F, 2013. Geomorphologic regionalization of China aimed at construction of nature reserve system. Acta Ecologica Sinica, 33(19): 6264-6276. (in Chinese)

Institute of Geography, Chinese Academy of Sciences (IGCAS), 1987. Geomorphological Mapping Specifications of $1: 1000000$ in China. Beijing: Science Press. (in Chinese)

Institute of Geography, Chinese Academy of Sciences (IGCAS), 1990. Atlas of Tibetan Plateau. Beijing: Science Press. (in Chinese)

Jin X M, Li Y, Fu B L et al., 2017. Spatiotemporal characteristics of wetland to farmland conversion processes in different geomorphological divisions during 1954-2015: A case study in the Sanjiang Plain north of the Wanda Mountains. Acta Ecologica Sinica, 37(10): 3286-3294. (in Chinese)

Li B Y, Pan B T, Cheng W M et al., 2013. Research on geomorphological regionalization of China. Acta Geographica Sinica, 68(3): 291-306. (in Chinese)

Li S G, Zhang W Y, 1953. Geology of China. Shanghai: Zhengfeng Press. (in Chinese)

Li Z Q, Liu X L, 1994. Geomorphic regionalization and agricultural evaluation of geomorphic features in Gansu. Journal of Gansu Agricultural University, 4(30): 444-449. (in Chinese)

Li Z Z, 1992. Geomorphic environment and urban construction of Urumqi city. Arid Land Geography, 15(1): 46-53. (in Chinese) 
Liu K, Wang X C, Ling T Q, 2009. Study on characteristics of highway geological disasters and third physiognomic regionalization in Guangxi. The Chinese Journal of Geological Hazard and Control, 20(1): 74-79. (in Chinese)

Liu Q Y, Cheng W M, Sun D Y et al., 2017. Distribution characteristics of historical mountain flood in China. Journal of Geo-information Science, 19(12): 1557-1566. (in Chinese)

Pamsay H G, Huber M I, 1987. The Techniques of Structural Geology. UK: Academic Press.

Ren J S, Wang Z X, Chen B W et al., 1999. The Tectonics of China from a Global View: A Guide to the Tectonic Map of China and Adjacent Regions. Beijing: Geological Publishing House. (in Chinese)

Resource Zoning Committee of Chinese Academy of Sciences (RZCCAS), 1959. Geomorphological Regionalization of China (the first draft). Beijing: Science Press. (in Chinese)

Shen Y C, 1961. The discussion on geomorphological compartment. Geography, (8): 33-41. (in Chinese)

Summerfield M A, 2000. Geomorphology and Global Tectonics. UK: John Wiley \& Sons Ltd.

You L Y, Yang J C, 2013. Geomorphology in China. Beijing: Science Press. (in Chinese)

Zhao M, Cheng W M, Liu Q Y et al., 2016. Spatiotemporal measurement of urbanization levels based on multiscale units: A case study of the Bohai Rim Region in China. Journal of Geographical Sciences, 26(5): 531-548.

Zhao M, Cheng W M, Zhou C H et al., 2017. Spatial differentiation and morphologic characteristics of China's urban core zones based on geomorphologic partition. Journal of Applied Remote Sensing, 11(1): 016041.

Zhou C H, 2006. A Dictionary of Geomorphology. Beijing: China Water \& Power Press. (in Chinese)

Zhou C H, Cheng W M, Qian J K, 2009a. Digital Geomorphological Interpretation and Mapping from Remote Sensing. Beijing: Science Press. (in Chinese)

Zhou C H, Cheng W M, Qian J K et al., 2009b. Research on the classification system of digital land geomorphology of $1: 1000000$ in China. Journal of Geo-Information Science, 11(6): 707-724. (in Chinese)

Zhou T R, Shi Y F, Chen S P, 1956. A draft for topographic regionalization of China. In: Chinese Geography Record. Physical Compartmentalization Draft of China. Beijing: Science Press. (in Chinese) 